Wrocławskie Studia Wschodnie

23 (2019)

Wydawnictwo Uniwersytetu Wrocławskiego

DOI: $10.19195 / 1429-4168.23 .5$

\author{
Katarzyna MichalewiCZ \\ ORCID: 0000-0002-1011-906X \\ Uniwersytet Wrocławski
}

\title{
Relacje Polonii harbińskiej z ludnością japońską w latach 1932-1937
}

\section{Zarys sytuacji politycznej}

Zadaniem artykułu jest przedstawienie prywatnych i społecznych relacji Polonii harbińskiej z ludnością japońską w latach 1932-1937. Wydarzeniami granicznymi dla tego zagadnienia są: zajęcie Harbinu przez Armię Kwantuńską oraz początek II wojny chińsko-japońskiej. Jest on także kontynuacją artykułu Relacje Polonii harbińskiej z ludnościa chińska w latach 1932-1927, który ukazał się w 22 numerze „Wrocławskich Studiów Wschodnich” w 2018 roku.

W I połowie XX wieku Harbin był jednym z największych i najlepiej rozwiniętych miast na Dalekim Wschodzie. Cechował je także kosmopolityzm, ponieważ metropolię zamieszkiwało ponad dwadzieścia pięć różnych narodowości. Ella Maillart w swoim reportażu Wystanniczka specjalna do Mandżurii - $w$ zderzeniu z Imperium z 1934 roku wspomina: „Jeśli istnieje gdzieś współczesna wieża Babel, to może być nią tylko Harbin"1. Również Polacy mieli swoją reprezentację w tym mieście. W okresie swojej świetności polska kolonia liczyła około 7 tysięcy osób ${ }^{2}$. Tym samym Polonia harbińska, obok Polonii szanghajskiej, była najważniejszą i najliczniejszą polską diasporą w Chinach $^{3}$.

1 E. Maillart, Wystanniczka specjalna do Mandżurii - w zderzeniu z Imperium, Warszawa 2012, s. 65.

2 K. Yong-Deog, Kolonia polska w Mandżurii 1897-1949, Kraków 2001, s. 46-47.

3 Kim Yong Deoga, powołując się na dane Polskiego Komitetu Opiekuńczego podaje, że Polonia Chińska około 1941 roku liczyła 1212 osób, w tym 931 osób mieszkało w Harbinie. Natomiast jak podaje Jerzy Czajewski, na początku 1945 roku Polski Komitet Opiekuńczy objął opieką 1308 Polaków. Z tej grupy 1017 osób mieszkało w Harbinie, a 291 poza nim. Zob. K. Yong-Deog, op. cit., s.62; J. Czajewski, Polacy w Mandżurii, red. T. Krawczak, Szczecin 2015, s. 16. Z kolei według Witolda Radwana — prezesa Izby Handlowej w Harbinie — w 1934

Wrocławskie Studia Wschodnie 23, 2019

(C) for this edition by CNS 
Wydarzeniem, które wpłynęło na sytuację Polaków zamieszkujących obecną stolicę prowincji Heilongjiang, była aneksja chińskiej Mandżurii przez Japonię, którą poprzedzał tak zwany incydent mukdeński z 18 września 1931 roku ${ }^{4}$. Na początku 1932 roku wojska japońskie zajęły między innymi miasto Harbin, które niedługo później weszło w skład marionetkowego państwa Mańdżukuo $^{5}$. Mimo że za początek II wojny chińsko-japońskiej uznaje się dopiero rok 1937, to już od roku 1931 możemy mówić o okupacji japońskiej na zajętych przez Armię Kwantuńską terenach ${ }^{6}$.

Polski rząd starał się dyplomatycznie podejść do sprawy, aby nie ucierpiała liczna Polonia zamieszkująca Państwo Środka. Dlatego po aneksji Mandżurii przez Japonię 1 listopada 1932 roku powołał drugiego, obok uznawanego przez Chiny Jamesa Douglasa, konsula - Aleksandra Kwiatkowskiego, którego z kolei akceptowała strona japońska. Kadencja „nowego” konsula nachodziła więc na okres urzędowania jego poprzednika. Pierwszy z nich przestał pełnić swoje obowiązki dopiero 30 kwietnia 1933 roku $^{7}$. Ponadto polskie Ministerstwo Spraw Zagranicznych zalecało konsulowi Kwiatkowskiemu, aby systematycznie rozwijał swoje stosunki z lokalnymi władzami Mańdżukuo, a także aby zadbał o to, by postępowanie polskiej kolonii nie zostało w żaden sposób uznane przez siły japońskie za nieżyczliwe. Instrukcje te miały na celu zapewnienie ochrony polskiej mniejszości przed okrutnymi represjami. Konsul miał również za zadanie na bieżą-

roku w samym mieście żyło około 1500 Polaków, a poza nim, w całej Mańdżurii — 3000. Por. K. Yong-Deog, op. cit., s. 62; J. Czajewski, op. cit., s. 59.

${ }^{4}$ Aneksja chińskiej części Mandżurii przez Japonię trwała od września 1931 do marca 1932 roku. Odpowiedzialne za tak zwany incydent mukdeński były Armia Kwantuńska oraz skrajnie nacjonalistyczne stowarzyszenie Kwiat Wiśni Armii Kwantuńskiej. Była to reakcja na nieudolne rządy gabinetu ówczesnego japońskiego premiera Hamaguchi Osachi, które doprowadziły do kryzysu ekonomicznego w kraju — J.L. Margolin, Japonia 1937-1945. Wojna armii cesarza, Warszawa 2013, s. 72.

${ }^{5} \mathrm{Na}$ terenach zajętych przez armię japońską 7 marca 1932 roku ustanowiono marionetkowe państwo Mańdżukuo, które początkowo było republiką, a dopiero 1 marca 1934 stało się cesarstwem. Jego głową został były chiński cesarz Pu Yi. Sam Pu Yi najpierw sprawował funkcję prezydenta, a później został koronowany na cesarza - Historia polityczna Dalekiego Wschodu — od końca XVI wieku do 1945 roku, red. M. Składkowska, A. Dubiński, J. Żukow, Warszawa 1981, s. 416-417; M. Cabanowski, Tajemnice Mandżurii - Polacy w Harbinie, Warszawa 1993, s. $117-119$.

${ }^{6}$ Według niektórych historyków japońskich wydarzenia lat 1932-1945 należy postrzegać jako jeden konflikt zbrojny trwajacy nieprzerwanie 15 lat - J.L. Margolin, op. cit., s. 72. Chińscy historycy okres 1932-1945 dzielą natomiast na dwa etapy inwazji japońskiej, a za datę graniczną przyjmują rok 1931 - L. Cheng, B. Kerry, Encyclopedia of China, t. 3. Great Barrington, Massachusetts 2009, s. 1199.

${ }^{7}$ Historia dyplomacji polskiej, t. 3. 1975-1918, red. L. Bazylow, Warszawa 1982, s. 46.

Wrocławskie Studia Wschodnie 23, 2019

(C) for this edition by CNS 
co informować o sytuacji japończyków w Mandżurii oraz o poczynaniach Związku Sowieckiego w tym regionie ${ }^{8}$.

Kluczowymi źródłami dla badań nad tym zagadnieniem jest harbińska polonijna prasa. Najbardziej reprezentatywne są tutaj dwa tytuły wydawane przez polską organizację oświatowo-kulturalną: „Gospodę Polską”. Mowa tutaj o „Listach Harbińskich” i „Dalekim Wschodzie”, które ukazywały się ciągle przez pięć lat (od 1931 do 1936 roku) ${ }^{9}$. Nie sposób także przecenić wspomnień Polaków mieszkających w Harbinie. Są one nie tylko uzupełnieniem, lecz także stanowią punkt odniesienia do informacji zawartych $\mathrm{w}$ prasie ${ }^{10}$. Relacje te najczęściej ukazały się w piśmiennictwie polskim po II wojnie światowej ${ }^{11}$. Z tego też względu mają one przewagę nad prasowymi źródłami, gdyż na ich powstawanie nie miała wpływu japońska cenzura ${ }^{12}$. Uzupełnieniem dla tych wiadomości mogą być tomy ukazujące się w serii „Polskie Dokumenty Dyplomatyczne”, które pokazywały, jak daną sytuację w regionie postrzegały władze II Rzeczpospolitej. Najczęściej są to raporty, instrukcje oraz noty dyplomatyczne wydawane przez przedstawicieli polskiego Ministerstwa Spraw Zagranicznych. Innym ciekawym źródłem jest „Kwartalnik Wschód”, wydawany w latach 1930-1939 w Warszawie, którego redaktorem naczelnym był najpierw Jerzy Giedroyć, a później Włodzimierz

${ }^{8} 11$ grudnia, instrukcja naczelnika Wydziału Wschodniego dla konsula $w$ Harbinie w sprawie stosunków z władzami i przedstawicielami Japonii w Mańdżukuo (dok. nr 392), [w:] Polskie dokumenty dyplomatyczne 1936, red. S. Żerko, Warszawa 2011, s. 776.

${ }^{9}$ Obie gazety były publikowane w Harbinie na przestrzeni kilku lat, w przeciwieństwie do pozostałych pism, których żywotność zazwyczaj była wyjątkowo krótka. Zawierają one w dodatku wiele cennych informacji z życia codziennego członków Polonii harbińskiej, dzięki czemu stają się podstawowym źródłem danych o sytuacji społecznej, kulturalnej, religijnej i politycznej mniejszości polskiej w Harbinie. Ponadto „Daleki Wschód” wyróżniał się na tle pozostałych gazet objętością, jakością wydania, licznymi i przejrzystymi ilustracjami, a także bogactwem poruszanej tematyki. Zob. Polacy w Mandżurii..., s. 20.

${ }^{10} \mathrm{~W}$ artykule mianem „Harbińczyków” (pisanym dużą literą) określam członków Polonii harbińskiej, w odróżnieniu od „harbińczyków” (pisanych małą literą) jako mieszkańców miasta. Zastosowałam w ten sposób też zabieg stylistyczny, gdyż członkowie Polonii harbińskiej w odniesieniu do swojej polonijnej społeczności często określali się właśnie mianem „Harbińczyków”. Wiązało się to z tym, że uważali oni miasto za swoją „małą ojczyznę”, a Chiny za swój drugi dom.

11 Osoby zainteresowane tematyką i chcące poszerzyć swoją wiedzę na temat życia polskich mieszkańców Harbinu powinni przede wszystkim zajrzeć do wspomnień Edwarda Kajdańskiego - Wspomnienia z mojej Atlantydy, oraz Łucji Drabczak — Moje Chiny - wspomnienia z dzieciństwa. Swoimi przeżyciami podzielili się także między innymi: Jadwiga Pomierska, Leonard Spychalski, Emilia Czajewska, Konstanty Zduński, Teodor Wolny. Ich spisane wspomnienia, z wyjątkiem historii Jadwigi Pomierskiej, która została przedstawiona w artykule Harbin moja miłość, opublikowanym na łamach „Głosu Pomorza”, znajdują się obecnie w zbiorach Książnicy Pomorskiej i stanowią część tak zwanych Harbinariów.

12 Polacy w Mandżurii..., s. 20.

Wrocławskie Studia Wschodnie 23, 2019

(C) for this edition by CNS 
Bączkowski. Głównym celem czasopisma było przybliżenie polskiemu czytelnikowi specjalistycznej wiedzy na temat kultury, tradycji, zwyczajów i historii krajów Europy Wschodniej i Azji, a także zachęcenie do indywidualnych poszukiwań ${ }^{13}$. Na jego łamach sporadycznie pojawiały się też informacje, a nawet całe notatki i artykuły poświęcone działalności Polonii w Harbinie ${ }^{14}$.

\section{Związki rodzinne i przyjaźnie}

Polacy najczęściej nawiązywali kontakty z Japończykami będącymi członkami rodzin rosyjsko-japońskich. Najpierw byli zaznajamiani z ich rosyjską częścią, a następnie dzięki kontaktom $\mathrm{z}$ nią stopniowo zawierali relacje z jej japońskimi przedstawicielami. Leonard Spychalski wspomina, że przez pewien czas regularnie odwiedzał swoją serdeczną koleżankę Wierę, której matka była Rosjanką, a ojciec Japończykiem ${ }^{15}$. Natomiast Łucja Drabczak wzmiankuje, że syn ich bliskich rosyjskich znajomych - Wiktor — ożenił się z Japonką. Autorka dodaje, że po wkroczeniu wojsk radzieckich do Harbinu członkowie jej rodziny, narażając przy tym własne życie, pomogli kobiecie ukryć się, a następnie wyjechać z miasta ${ }^{16}$. Podobne wspomnienia z dzieciństwa ma Edward Kajdański, który opowiada o częstych wizytach w jego domu Japończyka Chiune Sugihary ${ }^{17}$ oraz jego żony Rosjanki —

13 Od redakcji, „Kwartalnik Wschód” 1, 1930, nr 1, s. 3.

14 Na przykład: ,,Jedyne polskie czasopismo w Azji”, recenzja Jan Reychmann, „, Kwartalnik Wschód” 2, 1931, nr 3, s. 30; Z Akademickiego Koła Charbińczyków w Krakowie, „Kwartalnik Wschód" 2, 1931, nr 3, s. 39; Przyjazd przedstawiciela polskiego przemystu w Chinach, „Kwartalnik Wschód” 2, 1931, nr 3, s. 39; Z życia Akademickiego Koła Charbińczyków w Krakowie, „Kwartalnik Wschód” 2, 1931, nr 4, s. 89; Polskie Akademickie Koło Badania Chin $w$ Charbinie, „Kwartalnik Wschód” 2, 1931, nr 4, s. 89; Nowe czasopismo Polskie w Harbinie, „Kwartalnik Wschód” 3, 1932, nr 5-6, s. 80-81; „Na Dalniem Wostokie”, recenzja E. Gutorewicz, „Kwartalnik Wschód” 3, 1932, nr 7-8, s. 120-121; Przegląd czasopism, „Kwartalnik Wschód” 5, 1934, nr 1, s. 93-94; K. Symonolewicz, Kolonje Polskie w Charbinie, „Kwartalnik Wschód" 5, 1934, nr 1, s. 70-75.

15 L. Spychalski, Moja Gondatiewka 2, „Na sopkach Mandżurii HCM” 1999, nr 68, Książnica Pomorska, Harbinaria Kserokopia Artykułów, nr inwentarzowy 3752.

16 Ł. Drabczak, Moje Chiny - wspomnienia z dzieciństwa, Gdańsk 2005, s. 40.

17 Chiune Sugihara był japońskim dyplomatą, ambasadorem oraz konsulem, który uratował kilka tysięcy Polaków i Litwinów żydowskiego pochodzenia. W latach 1923-1935 mieszkał w Harbinie, gdzie pracował między innymi w konsulacie generalnym Japonii oraz prowadził zajęcia z języka rosyjskiego w Akademii Harbińskiej. Po utworzeniu Mańdżukuo wielokrotnie wstawiał się za ludnością chińską. Następnie pracował w Ministerstwie Spraw Zagranicznych w Tokio, a od 1939 roku w japońskim konsulacie w Kownie. Za swoje dokonania został odznaczony między innymi Krzyżem za Ratowanie Życia (1993), Krzyżem Komandorskim Orderu Zasługi RP (1996) oraz Krzyżem Komandorskim z Gwiazdą Orderu Odrodzenia Polski (2007). Nazywany jest także japońskim Schindlerem — E. Pałasz Rutkowska, A.T. Romer, Historia stosunków polsko-japońskich 1904-1945, Warszawa 2009, s. 242-284.

Wrocławskie Studia Wschodnie 23, 2019

(C) for this edition by CNS 
Klaudii. Rodziny Sugiharów i Kajdańskich były wtedy z sobą blisko. Autor relacji zwracał się do nich „wujku Chiu” oraz „ciociu Kławo”. Wspomina też o rodzinnej fotografii, na której jako kilkulatek siedział na kolanach pana Sugihary, a jego matka rozmawia z panią Klaudią. Nierzadko też goście obdarowywali kilkuletniego Edwarda drogimi i ciekawymi prezentami. Pisarz zaznacza przy tym, że obywatel Kraju Kwitnącej Wiśni biegle posługiwał się językiem rosyjskim ${ }^{18}$. Należy tutaj jednak podkreślić, że przytoczone wspomnienia Kajdańskiego dotyczą przełomu lat dwudziestych i trzydziestych XX wieku, czyli sprzed okresu okupacji. Autor dodaje jednak, że pan Sugihara odwiedził jego ojca jeszcze kilka razy w 1932 oraz najprawdopodobniej raz w 1934 roku$^{19}$.

Jako ciekawostkę wspomnijmy jeszcze, jak wyglądała wówczas sprawa związków polsko-rosyjskich, które były znacznie częstsze niż rosyjko-japońskie. Przed II wojną światową Polacy mieszkający w Harbinie utrzymywali bardzo dobre relacje z członkami mniejszości rosyjskiej — Leonard Spychalski i Łucja Drabczak w swoich relacjach nierzadko wspominają o swoich przyjaźniach z Rosjanami. Jak z kolei podkreśla Walentyna Kaczan - Rosjanka, która wyszła za Polaka - Henryka Kaczana, a po wyjeździe z Harbina wraz z nim i swoimi dziećmi na stale osiedliła się w Elblągu małżeństwa polsko-rosyjskie nie były niczym nadzwyczajnym w harbińskim społeczeństwie ${ }^{20}$. Wielu członków Polonii harbińskiej było również trójjęzycznych — oprócz języka polskiego w równym stopniu znali rosyjski i trochę słabiej chiński ${ }^{21}$.

Członkowie polskiej społeczności w Harbinie często spędzali czas z przedstawicielami mniejszości rosyjskiej. W relacjach członków Polonii harbińskiej nierzadko przewija się motyw wspólnych odwiedzin, także z okazji prawosławnych świąt. Również polscy sportowcy regularnie zmagali się w towarzyskich meczach hokeja, koszykówki czy piłki nożnej z przeciwnikami z rosyjskich drużyn.

Jedyną, choć bardzo poważną rysą na relacjach polsko-rosyjskich w Harbinie w okresie II wojny światowej było zachowanie niektórych rosyjskich policjantów. Władze marionetkowego państwa Mańdżukuo zezwalały bowiem „białym” Rosjanom na szykanowanie Polaków. Jak zaznacza Kim Yong-Deog, za cichą zgodą nowych władz część Rosjan pracujących w policji zmuszała

18 E. Kajdański, Wspomnienia z mojej Atlantydy, Warszawa 2013, s. 118, 128.

19 Ibidem, s. 129.

${ }^{20}$ W. Kaczan, Relacja Walentyny Kaczan, spisana w listopadzie 2008 roku (rozmowa z Arkadiuszem Wetniakiem), cyt. za: A. Wełniak, Reemigranci polscy z Mandżurii w Elblagu, „Rocznik Elbląski” 22, 2009, s. 193.

${ }^{21}$ P. Olenkowicz, Tożsamość narodowa Polonii Harbińskiej, [w:] Polskie ślady na Dalekim Wschodzie. Polacy w Harbinie. Materiaty z konferencji naukowej zorganizowanej w Szczecinie w dniach 23-24 października 2008 r., red. A. Furier, Szczecin 2008, s. 163.

Wrocławskie Studia Wschodnie 23, 2019

(C) for this edition by CNS 
Polaków do zrzekania się obywatelstwa polskiego, oddawania im paszportów, pozbawiała członków Polonii pracy zarobkowej, a także utrudniała działalność polskich instytucji, w tym „Gospody Polskiej”22.

Znajomości czy wręcz przyjaźni bez „pośrednictwa” rosyjskiego było znacznie mniej, ale jak można wnioskować z opisów, były one bardziej intensywne. Informacji o takiej znajomości dostarczają nam Łucja Drabczak i Witold Leparski.

Chociaż autorka nie wspomina dokładnie, w jakich okolicznościach nawiązała kontakt z Japonką, najprawdopodobniej był to przypadek, a nie celowa znajomość. Barierę językową pokonywały, porozumiewając się na migi bądź dzięki rysowaniu na karteczkach. Kobieta częstowała ją różnymi japońskimi potrawami oraz słodyczami. Sama znajomość jednak musiała być utrzymywana w tajemnicy przed mężem kobiety. Autorka relacji przyznaje też, że nie mówiła o tym swojej mamie, a wyjścia tłumaczyła chęcią odwiedzenia koleżanki. Warto zauważyć, iż dziewczynka już wtedy domyślała się, że te wizyty mogą być nie zaakceptowane przez dorosłych, choć nie rozumiała przyczyny. Dopiero po latach zdała sobie sprawę, że jej sąsiedzi na pewno nie aprobowali takich kontaktów, gdyż w tym okresie miała miejsce okupacja japońska ${ }^{23}$. Jak już wspomniano, również żona żandarma ukrywała te wizyty przed mężem. Widać więc, że prywatne kontakty polsko-japońskie w tym czasie mogły być negatywnie odbierane przez obie strony. Należy jednak zaznaczyć, że ewentualny sprzeciw matki autorki wspomnień mógł wynikać przede wszystkim z lęku o bezpieczeństwo dziecka i narażenie całej rodziny na gniew żandarma, a dopiero później z obawy przed pogorszeniem relacji z chińskimi sąsiadami.

Interesujący w tym kontekście artykuł Witolda Leparskiego Podporucznik Masaru Shinohara (wspomnienie o znajomym żotnierzu japońskim) został opublikowany w 32 numerze „Dalekiego Wschodu” ${ }^{24}$. Opowiada on o niezwykłej przyjaźni autora z japońskim wojskowym. Najpierw Leparski wspomina zajęcie Harbinu przez armię japońską, nie opisuje jednak tego wydarzenia jako traumatycznego przeżycia, ale jak ciekawą historię. Dodaje również, że w ciągu roku poznał wielu żołnierzy, a wszystkie te kontakty pozostawiły u niego jak najlepsze wspomnienia, chociaż żałuje, że Japończycy bardzo mało wiedzieli o Polsce. Zachowanie oficerów ocenia jako kulturalne, chociaż zaznacza, że byli oni skryci, nieufni i taili swoją znajomość języka rosyjskiego. Wśród nich znajdowało się kilku katolików. Jakiś czas później Leparski miał poznać Shinoharę, który — jak zaznacza autor — stał się jego najlepszym towarzyszem. Ten Japończyk wiedział więcej o Polsce niż jego koledzy,

${ }^{22}$ K. Yong-Deog, op. cit., s. 64.

23 Ibidem, s. 26-27.

24 W. Leparski, Podporucznik Masaru Shinohara (wspomnienie o znajomym żotnierzu japońskim), „Daleki Wschód” 1933, nr 32, s. 11-13.

Wrocławskie Studia Wschodnie 23, 2019

(C) for this edition by CNS 
co ucieszyło Leparskiego. Autor nadmienia też, że zaprosił wojskowego na obchody z okazji rocznicy podpisania Konstytucji 3 Maja do siedziby „Gospody Polskiej”. Shinoharę zafascynowała polska kultura, a szczególnie polskie pieśni patriotyczne, których próbował się nauczyć. Jego ulubionym utworem, który ponoć śpiewał codziennie, była Pierwsza Brygada. Pieśń tę Shinohara nucił także, by dodać sobie otuchy podczas ciężkich walk z armią chińską i hunhuzami. Twierdził też, że ma ona w sobie coś, co rozpala krew każdego żołnierza, i kto z nią rusza do boju, ten musi zwyciężać. Japończyk podkreślał, że utwór dodawał mu dodatkowych sił w walce ${ }^{25}$.

Warto jednak zaznaczyć, że pojawienie się tej pieśni we wspomnieniach może wskazywać na propagandę piłsudczykowską. „Daleki Wschód” przedstawiał bowiem Józefa Piłsudskiego jako wybitnego męża stanu. Jednocześnie jednak jeden z członków Polonii harbińskiej — Aleksander Kosiński — wspomina, że pieśń My, Pierwsza Brygada była bardzo popularna wśród uczniów Gimnazjum im. Henryka Sienkiewicza. Ten utwór oraz inne pieśni legionowe miał poznać w szkole na zajęciach z muzyki, które prowadził pan Wyszyński — nauczyciel śpiewu oraz organista w kościele pw. św. Stanisława ${ }^{26}$.

Przyjaźń Leparskiego z Shinoharą niewątpliwie miała wpływ na sympatie polityczne autora. W jego opisie potyczki chińsko-japońskiej w okolicy Harbinu widać pozytywny stosunek do wojska japońskiego ${ }^{27}$. Z relacji można wysnuć wniosek, że sami Japończycy, mimo że nie wiedzieli o Polsce wiele, byli zainteresowani kulturą polską, a także byli skłonni poszerzyć swoją wiedzę na ten temat. Również relacje pomiędzy Polakami a Japończykami służącymi w armii miały układać się dobrze i być oparte na obopólnym zainteresowaniu, choć widoczny był dystans mieszkańców Kraju Kwitnącej Wiśni do obcych narodów (pomimo przyjaznego zachowania nie do końca byli szczerzy ze swoimi rozmówcami i nie ujawniali wszystkich informacji o sobie). Przyjaźń z Japończykiem musiała wywrzeć duży wpływ na życie Leparskiego i jego postrzeganie rzeczywistości, skoro w opublikowanych na łamach „Dalekiego Wschodu” wspomnieniach wkroczenie obcej armii do miasta opisywał jak defiladę, koncentrując się na szczegółach umundurowania. „Listy Harbińskie” opisują ten okres bowiem jako czas zamętu, zagrożenia i niepewności o jutro, choć Polonia harbińska nie była w tym czasie stroną

25 Przykładem może być relacja z uroczystości w siedzibie „Gospody Polskiej”, upamiętniających śmierć marszałka; artykuł wyraźnie gloryfikował jego postać. Zob. Żałobne uroczystości po ś.p. Pitsudskim w Harbinie, „Daleki Wschód” 1935, nr 63, s. 6-9.

26 A. Kosińska, A. Kosiński, Wspomnienia o Polskim Gimnazjum, [w:] Chiny w oczach Polaków - księga jubileuszowa z okazji 60-lecia nawiąania stosunków dyplomatycznych między Polska a Chińska Republika Ludowa, red. J. Wodarski, K. Zeidler, M. Burdelski, Gdańsk 2010, s. 111.

27 W. Leparski, op. cit., s. 11-13.

Wrocławskie Studia Wschodnie 23, 2019

(C) for this edition by CNS 
w konflikcie chińsko-japońskim ${ }^{28}$. Z kolei „Kwartalnik Wschód” wspomina, że walki na terenie Harbina pomiędzy wojskami japońskimi a ustępującymi oddziałami chińskimi były krwawe ${ }^{29}$. „Listy Harbińskie” wspominają też, że polska społeczność, aby nieść pomoc poszkodowanym działaniami wojennymi członkom diaspory i by bronić mienie zarówno prywatne, jak i wspólne przed ewentualnym rabunkiem, powołała wśród swoich członków specjalne „grupy samoobrony obywatelskiej"30.

\section{Relacje handlowe}

Polsko-japońskie kontakty rozwijały się również na płaszczyźnie świadczonych sobie przez obie strony usług. Drabczak wspomina, że gdy chorowała, jej babcia wzywała lekarza Japończyka ${ }^{31}$. Z notki zamieszczonej w 14 numerze „Listów Harbińskich” dowiadujemy się natomiast, że Polacy czasami pracowali także w japońskich firmach - w ogłoszeniu zamieszczonym w gazecie znajduje się wzmianka o członku Polonii harbińskiej, pracowniku jednego $\mathrm{z}$ japońskich przedsiębiorstw ${ }^{32}$.

Dodatkowo mieszkańcy Harbinu wynajmowali - czasami obowiązkowo, a czasami dobrowolnie, ale pod przymusem ekonomicznym - w swoich domach pokoje japońskim żołnierzom. Informacja, choć niebezpośrednia, o pobycie Japończyków w domach Polaków pojawia się między innymi w relacji Leperskiego. Autor dodaje, że zakwaterowani u niego oficerowie zachowywali się kulturalnie i cechowała ich grzeczność, chociaż byli nieuf$\mathrm{ni}^{33}$. Jadwiga Pomierska ma podobne wspomnienia — opisuje wynajmującego w jej domu pokój Japończyka jako bardzo kulturalnego i inteligentnego człowieka. Dodaje też, że jako oficer służył w misji wojennej w Harbinie. Według jej słów zaraz po kapitulacji Japonii popełnił samobójstwo ${ }^{34}$. Obecność takiego „lokatora” mogła także zabezpieczyć gospodarzy przed represjami ze strony przedstawicieli nowej władzy i ochronić całą rodzinę przed niebezpieczeństwem. Jan Zienkowicz wspomina, że japoński oficer, który mieszkał z jego rodziną, zachowywał się wobec nich bardzo kulturalnie. Jednocześnie zaznacza, że jako dziecko był świadkiem dramatycznej sceny, w której ten sam

28 L. Wleciat, Z trwożnych dni, „Listy Harbińskie” 1932, nr 4, s. 1-2.

29 K. Symonolewicz, op. cit., s. 70-75.

${ }^{30}$ M. Badkerski, Polska samoobrona obywatelska, „Listy Harbińskie” 1932, nr 4, s. 5; idem, Rozwiazanie Samoobrony Obywatelskiej, „Listy Harbińskie 1932, nr 5, s. 3.

31 Ł. Drabczak, op. cit., s. 47.

${ }^{32}$ H., Kronika miejscowa - pobicie szofera Polaka przez policję, „Listy Harbińskie” 1932, nr 14, s. 7.

${ }^{33}$ W. Leperski, op. cit., s. 11-13.

34 J. Pomierska, Harbin Moja Miłość (rozmowa z Mariuszem Nowickim), „Głos Pomorza” 19.10.2007, https://gp24.pl/harbin-moja-milosc/ar/4319867 (dostęp: 16.07.2019).

Wrocławskie Studia Wschodnie 23, 2019

(C) for this edition by CNS 
człowiek kazał zastrzelić złapanych chińskich partyzantów, a ich ciała wrzucić do rzeki Sungarii. Autor wspomina, że japońscy żołnierze nierzadko zachowywali się wyjątkowo okrutnie, gdyż ze ślepym posłuszeństwem wykonywali rozkazy swoich dowódców ${ }^{35}$.

Niekiedy jednak wojskowi zachowywali się skandalicznie również wobec właścicieli wynajmowanych mieszkań. Jerzy Czajewski wspomina:

Stryj mojej mamy miał dom w tej okolicy. Wybudował go na wynajem. I ten dom spodobał się japońskim oficerom, którzy go wynajęli i zrujnowali, nie płacąc za czynsz. W końcu powiedzieli mu, że musi im go sprzedać za niską cenę, bo zostaną z niego gruzy. Stryj nie miał wyboru, dom sprzeda1 ${ }^{36}$.

Nie tylko krewny autora wspomnień stracił swoje dobra w wyniku działań władz okupacyjnych. O tym, że takie zachowanie rządu Mańdżukuo było na porządku dziennym, poświadcza chociażby notatka wicedyrektora Departamentu Politycznego Tadeusza Kobylańskiego z rozmowy z posłem Ito i Wiceministrem Spraw Zagranicznych Mańdżukuo - Ohashim. Jednym z punktów rozmów było właśnie ,nieprzychylne ustosunkowanie się władz mańdżurskich do Polaków i licznych na tym tle incydenty, które nie otrzymały zadowalającego rozwiązania"37. Wspomniany problem jest też wymieniony w telegramie do ówczesnego posła przebywającego w Japonii — Tadeusza Romera $^{38}$. Podobny los spotkał między innymi najbogatszego Polaka mieszkającego w Mandżurii - Władysława Kowalskiego. Posiadał on koncesję leśną wzdłuż wschodniej linii Kolei Wschodniochińskiej, o powierzchni około 6 tysięcy $\mathrm{km}^{2}$, a także fabrykę sklejki w Starym Harbinie, która zatrudniała 7 tysięcy osób ${ }^{39}$. Najpierw w wyniku kryzysu ekonomicznego wywołanego okupacją Mandżurii przez Japonię utracił prawie cały majątek, a następnie w 1936 roku okupanci zmusili go do odsprzedania pozostałych dóbr japońskiej firmie Kondo. Nie tylko on stał się ofiarą nowej władzy. Lew Zikman — właściciel cukrowni, olejarni i gorzelni w Aszyche - w 1934 roku został zmuszony przez rząd Mańdżukuo do odsprzedania 51\% udziałów Japończykom ${ }^{40}$.

Członkowie Polonii harbińskiej starali się chronić przed działaniami Japończyków godzących w ich sytuację ekonomiczną. Jak podaje Marian Kałuski, w tym celu już w 1930 roku powstał Związek Kupców

35 Wspomnienia polskich harbińczyków z czasów wojny antyjapońskiej, „Chińskie Radio Międzynarodowe" http://polish.cri.cn/1141/2015/09/16/41s133625_2.htm (dostęp: 1.12.2016).

36 Ibidem.

37 [przed 30 kwietnia], notatka Naczelnika Wydzialu Wschodniego z rozmowy z wiceministrem spraw zagranicznych Mańdżukuo (dok. nr 176), [w:] Polskie dokumenty dyplomatyczne 1937, red. J.S. Ciechanowski, Warszawa 2012, s. 260-261.

386 lipca, telegram szyfrowy posła w Tokio na temat uznania de facto rządu Mańdżukuo (dok. nr 96), [w:] Polskie dokumenty dyplomatyczne 1937..., s. 467-468.

39 J. Czajewski, op. cit., s. 4.

40 Ibidem, s. 5.

Wrocławskie Studia Wschodnie 23, 2019

(C) for this edition by CNS 
i Przemysłowców Polskich, którego prezesem został Witold Radwan. Z inicjatywy nowej instytucji powołano Izbę Handlową, która wspierała tych obywateli II Rzeczypospolitej, którzy w wyniku działań nowego rządu Mańdżukuo utracili pracę ${ }^{41}$. Nowa organizacja nie tylko ściśle współdziałała z Polskim Konsulatem, lecz także miała bronić pozostałych polskich interesów. Świadczyć o tym może ogłoszenie, które ukazało się w 5 numerze „Listów Harbińskich”. Namawiało ono Polaków posiadających określone dobra (place, przedsiębiorstwa, domy, posiadłości) w Harbinie, aby niezwłocznie - maksymalnie do końca marca 1932 roku — zgłosili to do Polskiej Izby Handlowej w Harbinie. Jak dodawano w notce, sama usługa była bezpłatna; zaznaczano również, że w innym przypadku konsul nie będzie mógł bronić ich interesów ${ }^{42}$.

\section{Udział Japończyków w wydarzeniach organizowanych przez Polonię harbińską}

Wśród zagranicznych gości uczestniczących w różnych spotkaniach charytatywnych organizowanych przez stowarzyszenie „Gospoda Polska” kilkukrotnie pojawiali się także obywatele Kraju Kwitnącej Wiśni. Zazwyczaj wspierali oni wówczas daną inicjatywę finansowo. Na przykład w sprawozdaniu wpływów i wydatków wieczoru z dnia 5 listopada 1932 roku, mającego pomóc zebrać fundusze dla Pierwszej Polskiej Bursy w Harbinie, widnieje zapis, że Japończyk pan Mikotaze, aby wesprzeć akcję, zakupił trzy bilety honorowe ${ }^{43}$. Natomiast wśród japońskich darczyńców, którzy wsparli Polski Bal Tradycyjny, który odbył się 11 lutego 1933 roku, znaleźli się między innymi pułkownik Kamawabura z żoną ${ }^{44}$. Z kolei na bal dobroczynny zorganizowany 9 listopada 1935 roku przez Zarząd Polskiego Towarzystwa Dobroczynności oraz Komitet Bursowy Pań przyszły członkinie towarzystwa japońskiego, które specjalnie przybyły na wydarzenie ubrane w tradycyjne stroje - kimona ${ }^{45}$.

Przedstawiciele Kraju Wschodzącego Słońca czasami uczestniczyli też w spotkaniach urządzanych przez polskie organizacje. W 31 numerze „Dalekiego Wschodu" możemy znaleźć informację o japońskim studencie Sugiyamie, który przebywał na Herbatce Polskiego Koła Studentów. Zaśpiewał on parę japońskich romansów i zatańczył kilka tradycyjnych tańców, między innymi taniec

${ }^{41}$ M. Kałuski, Polacy w Chinach, Warszawa 2001, s. 114.

42 J. Douglas, Ogłoszenie, „Listy Harbińskie” 1932, nr 5, s. 3, 4.

43 Sprawozdanie z wplywów i wydatków wieczoru 5 XI-32 r. na korzyść 1-ej Polskiej Bursy w Hrabinie, ,Głos Studenta” 1933, nr 7, s. 17.

${ }^{44}$ Kronika Miejscowa, „Daleki Wschód” 1933, nr 37-38, s. 15-16.

45 Kronika Miejscowa, „Daleki Wschód” 1935, nr 66, s. 12-16.

Wrocławskie Studia Wschodnie 23, 2019

(C) for this edition by CNS 
samuraja oraz taniec z mieczem. Na spotkanie, które odbyło się 18 stycznia 1933 roku, przybyło wielu gości w różnym wieku. Obecni byli również konsul polski James Douglas oraz Prezes Stowarzyszenia „Gospoda Polska” Leon Wlecia4 ${ }^{46}$.

Nieoficjalne społeczne kontakty z Japończykami były jednak nieliczne i ograniczone, aczkolwiek i one odgrywały pewną rolę w życiu tutejszej polskiej społeczności. Można także odnieść wrażenie, że to mieszkańcy Kraju Kwitnącej Wiśni bardziej interesowali się wydarzeniami w polskiej kolonii niż na odwrót, brakuje bowiem wzmianki o członkach Polonii harbińskiej, którzy udawaliby się z własnej inicjatywy na uroczystości organizowane przez społeczność japońską.

\section{Religia}

Polsko-japońskie relacje na tej płaszczyźnie wyglądają dość nikle, aczkolwiek mimo wszystko były budowane. Leonard Spychalski wspomina, że wśród uczestników procesji Bożego Ciała, oprócz Polaków, Chińczyków i Francuzów, można było spotkać także Japończyków ${ }^{47}$. Maria Skowron dodaje, że również w trakcie okupacji pozwalano katolikom na obchodzenie tego święta, a władze japońskie zezwalały na organizację procesji ${ }^{48}$.

\section{Sport}

Kontakty polsko-japońskie rozwijały się także dzięki sportowi. O sportowych zmaganiach polskiej drużyny piłki nożnej, która grała z Rosjanami, Japończykami, Koreańczykami i Chińczykami, wspomina Leonard Spychalski ${ }^{49}$.

Polacy mieli jednak szansę zmierzyć się z Japończykami nie tylko podczas meczów piłki nożnej, lecz także podczas rozgrywek hokeja. W marcu 1933 roku drużyna hokejowa Nowego Sportowego Towarzystwa w Harbinie rozegrała zwycięski mecz z reprezentacją japońską. Kapitanem polskiej drużyny był członek Związku Młodzieży Polskiej w Harbinie - Michał Antusiewicz, który według zawodników z Japonii miał być najlepszym graczem na Dalekim Wschodzie ${ }^{50}$. Zgodnie $\mathrm{z}$ informacjami $\mathrm{z}$ japońskiej gazety „Osaka Manichi” nasz zawodnik był najlepszym hokeistą w Mańdżukuo ${ }^{51}$.

46 Herbatka P.K.S., „Daleki Wschód” 1933, nr 31, s. 15.

${ }^{47}$ L. Spychalski, Mój Harbin - wspomnienia o kraju dzieciństwa, [w]: Polskie ślady..., s. 195.

48 Wspomnienia polskich harbińczyków...

49 L. Spychalski, Moja Gondatiewka 2, „Na Sopkach Mandżurii HCM” 1999, nr 68, s. 20.

50 Polak najlepszym hokeista w Harbinie, „Daleki Wschód” 1933, nr 34, s. 8.

51 A. Winiarz, Wychowanie fizyczne i sport w życiu Polonii mandżurskiej, „Prace Naukowe Akademii im. Jana Długosza w Częstochowie. Pedagogika” 20, 2012, s. 358.

Wrocławskie Studia Wschodnie 23, 2019

(C) for this edition by CNS 


\section{Zainteresowanie Polaków kulturą japońską}

Członkowie Polonii harbińskiej interesowali się także kulturą japońską, chociaż w znacznie mniejszym zakresie niż kulturą chińską. Za najciekawsze informacje uważali te, które mogły okazać się przydatne w tamtejszych realiach politycznych. Najczęściej wiedzę o Cesarstwie Japonii obywatele II Rzeczypospolitej mieszkający w Harbinie czerpali z prasy, przede wszystkim z „Listów Harbińskich” i „Dalekiego Wschodu”. Na łamach tych gazet ukazywały się artykuły dotyczące kultury i dorobku Kraju Kwitnącej Wiśni. Samych informacji było znacznie mniej niż tych dotyczących Państwa Środka, a problematyka, chociaż różnorodna, nie była bogata, aczkolwiek samo pojawienie się tej tematyki może świadczyć o zmieniającej się sytuacji politycznej w Harbinie i coraz większym udziale Japończyków w życiu miasta.

Artykuły w większości dotyczyły tradycji japońskich. I tak w numerze 32 „Dalekiego Wschodu” znajduje się tekst opisujący symbolikę koguta w mitologii i wierzeniach japońskich. Został on napisany, gdyż w momencie ukazania się numeru według chińskiego kalendarza ${ }^{52}$ miał się rozpocząć Rok Koguta $^{53}$. W kolejnym numerze możemy natomiast zapoznać się z japońską legendą o tym, jak Bóg stworzył kobietę ${ }^{54}$. Jest to zjaponizowana wersja historii biblijnej o stworzeniu Ewy, według której kobieta miała powstać nie z żebra — to bowiem w tej opowieści ukradł pies — ale z ogona tego sympatycznego zwierzęcia. Redakcja zamieszczała również informacje dotyczące społeczeństwa japońskiego. Wśród tego typu artykułów znalazł się na przykład tekst poświęcony japońskim dzieciom, roli szkoły w ich życiu, a także metodom wychowawczym. Autor w swojej pracy wysoko ocenia poziom systemu oświaty w Kraju Kwitnącej Wiśni. Zauważa, że kluczową rolę odgrywa tutaj dyscyplina, która jest jednak oparta nie na strachu, ale na szacunku i sympatii do pedagogów. Sama szkoła ma być natomiast drugim domem rodzinnym. Wskazuje też na starania państwa o wykształcenie mło-

52 Chiński kalendarz składa się z dwunastoletnich cykli. Według niego do każdego roku przypisane jest jedno z dwunastu zwierząt: szczur, bawół, tygrys, królik, smok, wąż, koń, koza/ owca, małpa, kogut, pies bądź świnia. Wspomniane znaki następują po sobie zawsze w tej samej kolejności. Niezależnie od zwierzęcia, do każdego roku przypisany jest jeden żywioł: metal, woda, drewno, ogień lub ziemia. Również one następują po sobie w odpowiedniej kolejności, chociaż należy tutaj zaznaczyć, że dany żywioł zmienia się nie co rok, ale co dwa lata. Oba cykle w połączeniu dają dużo większy cykl $(12 \times 5)$, co sprawia że ta sama kombinacja zwierzę plus żywioł pojawia się tylko raz na sześćdziesiąt lat. Według chińskiego horoskopu na podstawie tych dwóch informacji można nie tylko ustalić charakter ludzi, którzy się urodzili w danym roku, lecz także przewidzieć trendy w gospodarce, kulturze oraz polityce w tym okresie.

${ }^{53}$ Rok Koguta, „Daleki Wschód” 1933, nr 32, s. 12-13.

54 P.O., Jak Bóg stworzyt kobietę - legenda japońska, „Głos Studenta” 1933, nr 7, s. 14-15.

Wrocławskie Studia Wschodnie 23, 2019

(C) for this edition by CNS 
dzieży, aby w przyszłości mieć dobrych obywateli i żołnierzy ${ }^{55}$. W innym artykule poruszającym podobną tematykę opisano rolę i pozycję kobiet w dawnej i współczesnej Japonii. Warto dodać, że ukazał się on w ramach cyklu Kobieta Dalekiego Wschodu ${ }^{56}$.

Pojawiały się też teksty na wskroś politologiczne. I tak w podwójnym numerze 51-52 „Dalekiego Wschodu” znalazł się obszerny artykuł Ustrój państwowy i progres Japonii autorstwa Franciszka Arkina. Autor w skrócie przedstawia w nim historię Kraju Wschodzącego Słońca, a następnie skupia się na opisaniu działalności rządu oraz sądownictwa. Opowiada też o japońskim systemie edukacji oraz gospodarce i przemyśle. Kult cesarza i edukację zgodną z politycznymi wytycznymi porównuje do kultu jednostki w oświacie w Związku Radzieckim. Pod koniec wspomina, że Japonia po wystąpieniu z Ligii Narodów dąży nie do rozbrojenia, ale równości zbrojeń. Zaznacza także, że staje się ona mocarstwem, $z$ którym musi się liczyć cały świat ${ }^{57}$. Z kolei w numerze 58 „Dalekiego Wschodu” możemy zapoznać się z artykułem pod tytułem Japonia jako współczynnik gospodarki światowej autorstwa Arkina ${ }^{58}$. W „Dalekim Wschodzie” zamieszczano także artykuł krajoznawczy poświęcony najpiękniejszym miejscom w Japonii — jest on przedrukiem z „Kurjera Polskiego"59.

„Daleki Wschód” informował również o ciekawych miejscach i o wydarzeniach w Japonii, które były szczególnie ważne dla Polaków. I tak w numerze 34 wspomniano o postawieniu w japońskiej dzielnicy Jowezama krzyża upamiętniającego trzechsetną rocznicę męczeństwa katolików. Inicjatorem akcji miał być polski duchowny i misjonarz ojciec Józef Świętek. Jak podaje gazeta, miał być to pierwszy krzyż publiczny w Japonii ${ }^{60}$. Natomiast w podwójnym numerze 18-19 „Listów Harbińskich” wspomniany jest japoński poeta Sasaki Nobutsune, który miał w 1903 roku skomponować wiersz na cześć Polaków walczących o niepodległość. Historię o ich bohaterstwie miał poznać dzięki Sieroszowskiemu ${ }^{61}$. Inny poetycki wątek odnajdziemy w numerze 59 „Dalekiego Wschodu”, w którym możemy przeczytać wiersz Aleksandra Janta-Połczyńskiego" zatytułowany Tokio. Poeta porusza w utworze kwestię zagrożenia egzystencji mieszkańców tego miasta z powodu ciągłych i niespodziewanie występujących wstrząsów sejsmicznych ${ }^{62}$.

55 F. Arkin, Dziecko japońskie, „Daleki Wschód” 1933, nr 34, s. 15.

56 F. Arkin, Kobieta Dalekiego Wschodu, „Daleki Wschód” 1934, nr 59, s. 9-12.

57 F. Arkin, Ustrój państwowy i progres Japonii, „Daleki Wschód” 1934, nr 51-52, s. 7-10.

58 F. Arkin, Japonia jako wspótczynnik gospodarki światowej, „Daleki Wschód” 1934, nr 58, s. $10-13$.

59 Ad. Ka, Przez wewnętrzne Morze Japońskie, „Daleki Wschód” 1935, nr 61, s. 4-7.

${ }^{60}$ Krzyż na miejscu męczeństwa, „Daleki Wschód” 1933, nr 34, s. 7.

${ }^{61}$ K. Seyfried, The Japanese fan, „Listy Harbińskie” 1932, nr 7, s. 4.

${ }^{62}$ A. Janta-Połczyński, Tokio, „Daleki Wschód” 1934, nr 59, s. 16.

Wrocławskie Studia Wschodnie 23, 2019

(C) for this edition by CNS 


\section{Popularyzacja wiedzy o Japonii przez studenckie koła naukowe}

Polacy brali udział również w różnego rodzaju wykładach organizowanych przez polskie organizacje popularyzujące wiedzę o innych narodach. Uczestnicy spotkań podchodzili jednak z dużą ostrożnością do najnowszych propagandowych informacji dotyczących historii tego kraju. Przykładem może być spotkanie, „Młodego Prometeusza”, które 18 kwietnia 1934 roku odbyło się w siedzibie „Gospody Polskiej”. Pani Agafurowa wygłosiła odczyt na temat historii Złotej Ordy. Jej wypowiedź uzupełnił także pan Świt, który omówił źródła japońskie, według których Czyngis-chan miał być Japończykiem. W notatce wskazano jednak, że uczestnicy spotkania podeszli do tej teorii sceptycznie. Następnie odbyły się tańce i zabawy, chociaż — jak komentuje autor sprawozdania - goście nudzili się ${ }^{63}$. Innym udanym wydarzeniem, na którym poruszono tematykę kultury japońskiej, była wspomniana już Herbatka Polskiego Koła Studentów, której gościem honorowym był student Sugiyama.

Warto dodać, że jednym z celów Polskiego Koła Studenckiego w Harbinie było szerzenie wiedzy o Polsce, jej kulturze i historii nie tylko wśród Chińczyków, lecz także wśród Japończyków. Sama inicjatywa była według członków stowarzyszenia ważna, ponieważ Polacy byli myleni z Rosjanami. Ponadto w tych działaniach upatrywano szansy na nawiązanie bliższych i lepszych kontaktów z przedstawicielami Państwa Środka i Kraju Kwitnącej Wiśni ${ }^{64}$.

Jako ciekawostkę można nadmienić, że jeszcze parę miesięcy przed aneksją Mandżurii przez Japonię podobną rolę odgrywało Muzeum Orientalne działające przy Akademickim Kole Badania Chin. Warto tutaj dodać, że sama instytucja została założona przez inżyniera Kazimierza Grochowskiego. Siedziba placówki, której dyrektorem został właśnie Grochowski, znajdowała się na pierwszym piętrze Gospody Polskiej ${ }^{65}$. Jak podaje „Kwartalnik Wschód", muzeum cieszyło się wielkim uznaniem wśród naukowców zajmujących się Dalekim Wschodem, w gronie których znajdowali się Rosjanie, Chińczycy i Japończycy. Przedstawiciele tych trzech narodowości zwiedzili wspomnianą placówkę zimą 1930 roku. Muzeum Orientalistyczne współpracowało także ściśle z innymi pokrewnymi instytucjami na terenie Harbina, między innymi z państwowym chińskim muzeum i japońskim muzeum, poświęconemu historii Mandżurii ${ }^{66}$.

\footnotetext{
63 Z życia Młodego Prometeusza, „Daleki Wschód” 1934, nr 54, s. 21.

64 Młode polskie pokolenie na D.W. i jego zagadnienia, „Głos Studenta” 1933, nr 7, s. 15-16.

65 Muzeum Polskiego Koła Wschodoznawczego, „Daleki Wschód” 1934, nr 54, s. 21.

66 Polskie Akademickie Koło..., s. 89.
}

Wrocławskie Studia Wschodnie 23, 2019

(C) for this edition by CNS 


\section{Nauka języka japońskiego}

Wraz ze zmianą sytuacji w Mandżurii pojawiła się też coraz większa konieczność poznania, chociaż w stopniu podstawowym, języka japońskiego. Jak zaznacza Paulina Olenkowicz, większość mieszkańców Harbina była co najmniej dwujęzyczna. Wspomina również, że do pożądanych języków, oprócz chińskiego i rosyjskiego, dołączył japoński. Zaznacza przy tym, że ich znajomość nie wiązała się z wynarodawianiem, ale z szansą na jak najlepsze odnalezienie się $\mathrm{w}$ wielonarodowym mieście ${ }^{67}$. Tematyka ta pojawiła się także podczas dyskusji nad reformą polskiego szkolnictwa w Harbinie. Japoński jako jeden wśród przydatnych języków, które powinny być nauczane w szkole, wymienia między innymi Antoni Łata ${ }^{68}$ oraz profesor Jan Jaworski. Drugi z nich podkreśla, że jest to związane z obecną sytuacją polityczną i ekonomiczną ${ }^{69}$. Wspomniane postulaty zostały spełnione w 1934 roku, kiedy nastąpiła gruntowna reforma polskiego szkolnictwa w Harbinie, w związku z którą wśród dodatkowych zajęć znalazł się właśnie język japoński ${ }^{70}$.

Aleksander Kosiński tak wspomina naukę tego języka w gimnazjum:

Języka japońskiego uczyła nas pani Reut. Podręczniki do jego nauki pełne były bardzo ładnych, kolorowych rycin. Język japoński był łatwiejszy od chińskiego, miał dwa alfabety „,sylabowe", a znaki były prawie identyczne z chińskimi. Znając alfabet, można było czytać większość japońskich książek. Znaków w zasadzie używali ludzie z wyższym wykształceniem ${ }^{71}$.

\section{Podsumowanie relacji polsko-japońskich}

Analizując relacje polsko-japońskie, od razu można zauważyć kilka charakterystycznych cech. Japończycy, z którymi obywatele II Rzeczypospolitej utrzymywali kontakty, byli zazwyczaj członkami rodzin japońsko-rosyjskich. Wyjątkiem jest tutaj przyjaźń Witolda Leparskiego z Shinoharą i Łucji Drabczak z żoną żandarma. Nie bez znaczenia dla dalszego rozpatrywania tego zagadnienia jest fakt, że o prywatnych i zawodowych relacjach Polaków z Japończykami dowiadujemy się nie ze wspomnień Harbińczyków, lecz z muszących się liczyć z cenzurą tekstów zamieszczanych w „Listach Harbińskich” oraz „Dalekim Wschodzie”.

Dowiadujemy się z nich, że ludzie pochodzący z Kraju Kwitnącej Wiśni uczestniczyli w spotkaniach organizowanych przez polskie instytucje, między innymi „Gospodę Polskę”, polscy zawodnicy zmagali się z japońskimi druży-

${ }^{67}$ P. Olenkowicz, op. cit., s. 163.

68 A. Łata, Na przełomie, „Daleki Wschód” 1934, nr 54, s. 14.

69 J. Jaworski, Reforma szkoły polskiej w Harbinie, „Daleki Wschód” 1935, nr 64, s. 14-15.

${ }^{70}$ M. Kałuski, op. cit., s. 154-155; K. Yong-Deog, op. cit., s. 74.

71 A. Kosińska, A. Kosiński, op. cit., s. 112.

Wrocławskie Studia Wschodnie 23, 2019

(C) for this edition by CNS 
nami, a w procesji Bożego Ciała wspólnie modlili się wyznawcy Chrystusa tych dwóch narodowości. Jednak ze wspomnień Harbińczyków wynika, że w tych dwóch ostatnich przypadkach kontakty polsko-japońskie były bardzo rzadkie i jednostkowe. Podobna sytuacja miała również miejsce na płaszczyźnie wzajemnie świadczonych usług.

Wspomnienia Harbińczyków niestety nie dostarczają bogatej wiedzy o kulturze japońskiej. Wiązało się to z niewielką ilością nawiązanych wzajemnych kontaktów. Także motywacja do lepszego poznania dorobku oraz historii Cesarstwa Japonii nie była aż tak silna jak w wypadku zagadnień związanych z Państwem Środka. Ponadto zazwyczaj łączyła się z koniecznością odnalezienia się $\mathrm{w}$ okupowanym mieście, a nie chęcią poszerzenia wiedzy o swoich sąsiadach. Niemniej jednak ta tematyka również była obecna w kręgu zainteresowań polskiej społeczności.

Relacje o tym, jakoby sytuacja międzynarodowa w latach 1932-1936 bezpośrednio wpływała na społeczne i prywatne kontakty Polonii harbińskiej z Japończykami, są nieliczne. Brakuje też informacji, aby oddziaływała ona negatywnie bądź pozytywnie na te kontakty, które Polacy nawiązywali bądź już wcześniej zawierali z obywatelami Kraju Kwitnącej Wiśni. Można się jednak domyślać, że mała ilość znajomości polsko-japońskich miała związek z zaistniałą, nową sytuacją polityczną w Harbinie.

Jedną z nielicznych wskazówek świadczących za tą tezą jest wypowiedź Drabczak na temat jej znajomości z żoną japońskiego żandarma. Autorka wspominała, że gdyby jej spotkania z Japonką wyszły na jaw, mogłoby to zostać źle odebrane przez jej chińskich sąsiadów. Przyjaźń Leparskiego i Shinohary jest podobnym przykładem. W tym drugim przypadku do autentyczności samej historii należy podejść jednak z dużą ostrożnością, gdyż wpływ na jej umieszczenie na łamach prasy mogła mieć propaganda z Japonii. Ze wspomnianej relacji wynika, że Shinohara był obecny na obchodach święta Konstytucji 3 maja, które odbywały się w siedzibie „Gospody Polskiej”, co mogło mieć na celu zasugerowanie, że w tym konkretnym przypadku przyjaźń między Polakiem a japońskim wojskowym nie była odbierana negatywnie przez członków Polonii harbińskiej. Mając natomiast w pamięci wspomnienia Harbińczyków, wiemy, że wspomniane reakcje były albo neutralne albo negatywne. Warto też zauważyć, że o wizycie Shinohary w placówce „Gospodzie Polskiej” dowiadujemy się przypadkowo, więc samo wydarzenie, w myśl tej relacji, nie miałoby być czymś nadzwyczajnym. Leparski podkreśla bowiem nie to, że Japończyk udał się z nim na uroczystość, ale że jego kolegę zawiodło, że nie odśpiewano wtedy Pierwszej Brygady. O tym, że istnieje tutaj duże prawdopodobieństwo interwencji cenzury, poświadcza brak wiadomości o ocenie tej znajomości przez Chińczyków. W tym wypadku trudno jednak ostatecznie ustalić, czy powodem była celowa działalność

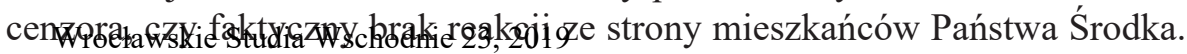

(C) for this edition by $\mathrm{CNS}$ 
Zażyłe stosunki z wojskowymi z Japonii były rzadkością, znaczna większość nawiązywanych prywatnych relacji dotyczyła cywili. O tym, dlaczego Polacy nie znaleźli miejsca na bliskie kontakty z przedstawicielami Armii Kwantuńskiej, informuje chociażby przypadek okrutnego potraktowania dziadka Romualda Oziewicza - Adama Rauta — przez japońskich żołnierzy. Wojskowi najpierw, nie informując o tym nawet jego krewnych, bezprawnie aresztowali starszego mężczyznę, a później wycieńczonego pozostawili samotnie w odległym miejscu na kilkudziesięciostopniowym mrozie ${ }^{72}$. Innym przykładem bezwzględności żołnierzy Armii Kwantuńskiej było aroganckie zachowanie oficerów Nipponu wobec stryja Jerzego Czajewskiego, którzy nie tylko zmusili go do niekorzystnej odsprzedaży domu, ale i wcześniej go zdemolowali. Widoczne było, że w obu przypadkach wojskowi pozwolili sobie na takie zachowanie wobec Polaków, wiedząc, że w obecnej sytuacji politycznej mogą czuć się bezkarnie. Autorzy obu relacji nie precyzują jednak, kiedy te zajścia miały miejsce, nie sposób więc określić, czy było to przed, czy po 1936 roku $^{73}$.

$\mathrm{Z}$ analizowanych źródeł nie wynika jasno, czy stosunki między II RP a Japonią miały swoje odzwierciedlenie w stosunkach w Harbinie. Z przytoczonych źródeł, choć nie zawsze jasno, wynika jednak, że armia japońska była postrzegana przez Polaków jako agresor, który bezprawnie zajął część terytorium Chin, a samo miasto znalazło się w 1932 roku pod okupacją japońską. Na skutek tego wydarzenia kontakty z przedstawicielami Nipponu musiały budzić negatywne emocje i udawało się je nawiązać tylko wtedy, gdy osobiste cechy charakteru Japończyków, jak na przykład chęć niesienia pomocy Chińczykom przez Chiune Sugiharę, usuwały dystans i nieprzyjazne uczucia, które budził okupant. Takie wyjaśnienie braku intensywności relacji polsko-japońskich jest najprostsze, ale zarazem właściwe. Nie można jednak przeoczyć faktu, że wzrost liczebności mniejszości japońskiej w tym mieście, znacząco zwiększający szansę na kontakty z obywatelami Kraju Wschodzącego Słońca, nastąpił dopiero po 1932 roku.

\section{Bibliografia}

\section{Źródła}

\section{Prasa}

„Daleki Wschód” 1933-1936, nr 31-32, 34, 37-38, 51-52, 54, 58-59, 61, 63-64, 66, 68.

„Głos Studenta” 1.03.1933.

„Kwartalnik Wschód” 1930, nr 1, 4; 1934, nr 13.

„Listy Harbińskie” 1932, nr 4, 5, 7, 14.

72 Wspomnienia polskich harbińczyków...

${ }^{73}$ Wbödkawskie Studia Wschodnie 23, 2019

(C) for this edition by CNS 


\section{Wspomnienia}

\section{Rękopisy archiwizowane w Książnicy Pomorskiej w Dziale Rękopisów}

Czajewska E., Wspomnienia z lat młodości w Harbinie, nr inwentarzowy 3390.

Drabczak Ł., Niezapomniany Harbin, nr inwentarzowy 3451.

Spychalski L., Moja Gondatiewka, materiały dotyczące Leonarda Spychalskiego Harbinaria, nr inwentarzowy 3459.

Spychalski L., Mój Harbin, nr inwentarzowy 3518.

Zduński K., Chiński Polak z Turkmenistanu (wspomnienia z bardzo odległej przeszłości), nr inwentarzowy 4420.

\section{Wspomnienia opublikowane}

Drabczak Ł., Moje Chiny. Wspomnienia z dzieciństwa, Gdańsk 2005.

Kaczan W., Relacja Walentyny Kaczan, spisana w listopadzie 2008 roku (rozmowa z Arkadiuszem Wetniakiem), cyt. za: A. Wełniak, Reemigranci polscy z Mandżurii w Elblagu, „Rocznik Elbląski” 22, 2009, s. 192-197.

Kajdański E., Wspomnienia z mojej Atlantydy, Warszawa 2013.

Kosińska A., Kosiński A., Wspomnienia o Polskim Gimnazjum, [w:] Chiny w oczach Polaków. Księga jubileuszowa z okazji 60-lecia nawiązania stosunków dyplomatycznych między Polska a Chińska Republika Ludowa, red. J. Wodarski, K. Zeidler, M. Burdelski, Gdańsk 2010, s. 105-118.

Miasto lodu - Harbin pod okupacja japońska w oczach świadków, „Chińskie Radio Międzynarodowe", http://polish.cri.cn/1221/2015/09/01/341s133469.htm (dostęp: 1.12.2016).

Pomierska J., Harbin moja miłość (rozmowa z Mariuszem Nowickim), „Głos Pomorza” 19.10.2007, https://gp24.pl/harbin-moja-milosc/ar/4319867 (dostęp: 16.07.2019).

Spychalski L., Mój Harbin — wspomnienia o kraju dzieciństwa, [w:] Polskie Ślady na Dalekim Wschodzie. Polacy w Harbinie. Materiaty z konferencji naukowej zorganizowanej w Szczecinie $w$ dniach 23-24 października 2008 r, red. A. Furier, Szczecin 2008, s. $192-203$.

Spychalski L., Moja Gondatiewka 2, „Na sopkach Mandżurii HCM” 1999, nr 68, Książnica Pomorska, Harbinaria Kserokopia Artykułów, nr inwentarzowy 3752.

Wspomnienia Polskich Harbińczyków z czasów wojny antyjapońskiej, „Chińskie Radio Międzynarodowe", http://polish.cri.cn/1141/2015/09/16/41s133625_2.htm (dostęp: 1.12.2016).

\section{Archiwalia}

\section{Polskie Dokumenty Dyplomatyczne}

11 grudnia, instrukcja naczelnika Wydziatu Wschodniego dla konsula $w$ Harbinie $w$ sprawie stosunków z władzami i przedstawicielami Japonii w Mańdżukuo (dok. nr 392), [w:] Polskie Dokumenty Dyplomatyczne 1936, red. S. Żerko, Warszawa 2011, s. 776.

[przed 30 kwietnia], notatka Naczelnika Wydziału Wschodniego z rozmowy z wiceministrem spraw zagranicznych Mańdżukuo (dok. nr 176), [w:] Polskie Dokumenty Dyplomatyczne 1937, red. J.S. Ciechanowski, Warszawa 2012, s. 260-261.

Wrocławskie Studia Wschodnie 23, 2019

(C) for this edition by CNS 
6 lipca, telegram szyfrowy posta w Tokio na temat uznania de facto rzadu Mańdżukuo (dok. nr 96), [w:] Polskie Dokumenty Dyplomatyczne 1937, red. J.S. Ciechanowski, Warszawa 2012, s. 467-468.

\title{
Opracowania
}

Cabanowski M., Tajemnice Mańdżurii - Polacy w Harbinie, Warszawa 1993.

Cheng L., Kerry B., Encyclopedia of China, t. 3, Great Barrington 2009.

Czajewski J., Polacy w Mańdżurii, Szczecin 2015.

Historia dyplomacji polskiej, t. 3. 1795-1918, red. L. Bazylow, Warszawa 1982.

Historia polityczna Dalekiego Wschodu — od końca XVI wieku do 1945 roku, red. M. Składkowska, A. Dubiński, J. Żukow, Warszawa 1981.

Kałuski M., Polacy w Chinach, Warszawa 2001.

Margolin J.L., Japonia 1937-1945. Wojna armii cesarza, Warszawa 2013.

Olenkowicz P., Tożsamość narodowa Polonii harbińskiej, [w:] Polskie Ślady na Dalekim Wschodzie. Polacy w Harbinie. Materiały z konferencji naukowej zorganizowanej w Szczecinie w dniach 23-24 października 2008 r., red. A. Furier, Szczecin 2008, s. 155-168.

Pałasz-Rutkowska E., Romer A.T., Historia stosunków polsko-japońskich 1904-1945, Warszawa 2009.

Polacy w Mandżurii - Poles in Manchuria (1897-1949), red. T. Krawczak, Szczecin 2015.

Winiarz A., Wychowanie fizyczne i sport w życiu Polonii mandżurskiej, „Prace Naukowe Akademii im. Jana Długosza w Częstochowie. Pedagogika” 20, 2012, s. 351-361.

Yong D.K., Kolonia polska w Mandżurii 1897-1949, Kraków 2001.

Yong D.K., Życie kulturalne Polaków w Mandżurii w latach 1897-1947, „Postcriptum Polonistyczne" 2 (6), 2010, s. 117-142.

\section{Связи харбинской Полонии с японским населением в 1932-1937 годах}

\author{
Резюме
}

В первой половине XX века в Харбине проживала харбинская Полония, насчитывающая несколько тысяч человек. Она устанавливала контакты с другими жителями города, как с китайцами, так и с представителями народных меньшинств. Значительное влияние на эти связи оказывала политическая ситуация: занятие японцами северо-восточной части Китая и создание марионеточного государства Маньчжоу-го.

Упомянутая ситуация оказала особое влияние на формирование связей харбинской Полонии с японцами. Контакты с представителями армии были или негативные, или, реже, нейтральными. Личные контакты были также спорадичными и чаще ограничивались только знакомством с японцами, которые были членами российских семей. Интерес членов харбинской Полонии к культуре и японскому языку был также слабый и обусловливался единственно желанием лучшего понимания тогдашней политической ситуации.

Важнейшим дополнительным источником информации для характеристики этого периода является, прежде всего, полонийная пресса: «Дальний Восток» и «Ведомости харбинские», а также журнал «Ежеквартальник Восток».

Wrocławskie Studia Wschodnie 23, 2019

(C) for this edition by CNS 


\section{The relations between members of the Polish diaspora and Japanese people in Harbin, 1932-1937}

\section{Summary}

A numerous Polish diaspora (several thousands) was living in Harbin in the first half of the 20th century. The members of the Polish community tried to establish relations with Chinese people and members of other national minorities. These relationships were most strongly influenced by the political situation: the annexation of the north-east part of China's territory by the Japanese, and established there by Japan a puppet state - Manchukuo.

These situations had a peculiar impact on the Polish-Japanese relationships in Harbin. The contacts of the Polish people with the Japanese army were negative or, rarely, neutral. Private contacts were also occasional. Frequently, members of the Polish diaspora maintained contact with only those Japanese people who were members of Russian families. The interest in Japanese culture and Japanese language was also low. It was connected with trying to better understand the contemporary political situation.

The main and key sources for this period are: the press of the Polish diaspora like: Daleki Wschód (Far east) and Listy Harbinskie (Letters from Harbin) and memoirs of the members of the Polish diaspora. The additional, supplementary sources which enlarge the knowledge about these times are: Polskie Dokumenty Dyplomatyczne (Polish diplomacy documents) and also Kwartalnik Wschód (Quarterly journal east). 